\title{
Submandibular Duct Stone
}

National Cancer Institute

\section{Source}

National Cancer Institute. Submandibular Duct Stone. NCI Thesaurus. Code C35629.

A concretion in the submandibular duct. 